\title{
A Method for the Determination of Tobacco-specific Nitrosamines (TSNA), Nitrate and Nitrite in Tobacco Leaves and Processed Tobacco*
}

\author{
by Bertold Spiegelhalder, Stanislaw J. Kubacki". and Sophia Fischer \\ Institute of Toxicology and Chemotberapy, German Cancer Research Center, \\ Heidelberg, Federal Republic of Germany
}

Dedicated to Prof. Dr. R. Preussmann on the occasion of his 60th birthday.

\section{SUMMARY}

A method for the simultaneous determination of tobacco-specific nitrosamines [TSNA], $N^{\prime}$-nitrosonornicotine [NNN], 4-(methylnitrosamino)-1-(3-pyridyl)1-butanone [NNK], $N$ 'nitrosoanabasine [NAB] and $N$-nitrosoanatabine [NAT], as well as nitrate and nitrite in tobacco leaves and processed tobacco was developed. The analytical procedure included aqueous extraction of tobacco leaves and processed tobacco respectively under alkaline conditions in the presence of an antibacterial agent and, for TSNA analysis, a further clean-up of the aqueous extract by liquid-liquid partition extraction (kieselguhr column extraction), removal of nicotine, and determination of the nitrosamines by gas chromatography in combination with chemiluminescence detection. It is demonstrated that $N^{\prime}$-nitrosopentylpicolylamine [NPePicA] as well as $\mathrm{N}$-nitrosodibenzylamine [NDBenzA] can be used for internal standardization. For clean-up two different extraction procedures can be utilized: alkaline extraction on kieselguhr / ascorbic acid extraction columns or acidic extraction on kieselguhr including prior destruction of nitrite with sodium azide. The recoveries of the internal standards were in a similar range $(73 \%-96 \%)$ as those of the TSNA. The analysis of nitrite and nitrate was carried out according to standard analytical procedures using the alkaline aqueous extract. The determination of nitrate and nitrite showed high accuracy and reproducibility: It is demonstrated that, under the conditions described, artifact formation did not occur even when

\footnotetext{
- Received: 29th June 1988 - accepted: 30h August 1988. ,

** Visiting scientist, Department of Food Analysis, Institute of the Fermentation Industry, Rakowiecka 36, PL-02-532 Warszawa, Poland.
}

nitrite was present. The method described is specifically applicable for the simultaneous determination of TSNA and nitrate/nitrite in tobacco leaves.

\section{ZUSAMMENFASSUNG}

Es wurde eine Methode zur gleichzeitigen Bestimmung tabakspezifischer Nitrosamine [TSNA], $N^{\prime}$-Nitrosonornicotin [NNN], 4-(Methylnitrosamino)-1-(3-pyridy])-1-butanon [NNK], $N$-Nitrosoanabasin [NAB] und $N^{\prime}$-Nitrosoanatabin [NAT], sowie von Nitrat und Nitrit in Tabakblattgut und verarbeitetem Tabak entwickelt. Zunächst wurde das Probenmaterial (Tabakblattgut bzw. verarbeiteter Tabak) im wäßrigen Medium unter schwach alkalischen Bedingungen in Gegenwart eines Bakterizides extrahiert. Für die TSNA-Bestimmung wurde der wäßrige Extrakt durch Flüssigflüssig-Verteilung unter Verwendung einer KieselgurSäule gereinigt. Der Extrakt wurde von Nicotin befreit, und nach Konzentrierung wurden die Nitrosamine gaschromatographisch getrennt und mitrels Chemolumineszenz bestimmt. Die quantitative Auswertung erfolgte durch Vergleich dex Signalflächen mit Hilfe interner Standards. Sowohl $N^{3}$-Nitrosopentylpicolylamin [NPePicA] als auch $N$-Nitrosodibenzylamin [NDBenż] konnten als interne Standards verwendet werden. Die Wiederfindung der beiden internen Standards lag in einem mit jenem der TSNA vergleichbaren Bereich zwischen 73 und $96 \%$. Fūr die Flüssig-flüssigVerteilung konnten $z$ wei verschiedene Extraktionsverfahren verwendet werden: Extraktion alkalischer Probelösungen an Kieselgur/Ascorbinsāure-Säulen oder Extrạktion saurer Probelösungen an Kieselgur nach 
Zersetzung von Nitrit mit Natriumazid. Für die Bestimmung von Nitrat und Nitrit nach Standardmethoden wurden ebenfalls die schwach alkalischen wäßrigen Probenextrakte eingesetzt. Es konnte gezeigt werden, daß eine artifizielle Bildung von Nitrosaminen, selbst in Gegenwart von Nitrit, nicht erfolgt. Die beschriebene Methode ist besonders für die gleichzeitige Bestimmung von Nitrat, Nitrit und TSNA in Tabakblattgut geeignet.

\section{RESUME}

Les auteurs ont mis au point une méthode permettant de doser simultanément les nitrosamines spécifiques du tabac [TSNA], $N^{\prime}$-nitrosonornicotine [NNN], 4-(méthylnitrosamino)-1-(pyridyl-3)-1-butanone [NNK], $N^{\prime}$ nitrosoanabasine [NAB] et $N^{\prime}$-nitrosoanatabine [NAT], ainsi que les nitrates et nitrites contenus dans les feuilles de tabac et dans le tabac manufacturé. Les échantillons (feuilles de tabac ou tabac manufacturé) ont étê extraits tout d'abord dans un milieu aqueux faiblement alcalin en présence d'un bactéricide. Pour le dosage des TSNA, l'extrait aqueux a été purifié par extraction liquide-liquide sur colonne de terres infusoires. L'extrait a été débarrassé de la nicotine et, après concentration, les nitrosamines ont été séparées par chromatographie en phase gazeuse puis dosées par chimioluminescence. L'analyse quantitative a été réalisée par comparaison des surfaces des signaux à l'aide d'un étalon interne. Il a été possible de prendre comme étalons internes aussi bien la $N^{\prime}$-nitrosopentylpicolylamine [NPePicA] que la $N$ 'nitrosodibenzylamine [NDBenzA]. La récupération des deux étalons internes s'est située dans une plage de $73 \%$ a $96 \%$, comparable à celle des TSNA. Pour le fractionnement liquideliquide, il a aussi été possible d'utiliser deux procédés d'extraction différents: extraction de solutions alcalines d'échantillon sur colonnes de terres infusoires / acide ascorbique ou bien extraction de solutions acides sur terres infusoires après décomposition des nitrites par l'azoture de sodium. La détermination des teneurs en nitrates et nitrites selon des procédés classiques a aussi été effectuée à partir des échantillons en solution faiblement alcaline. Il a été possible de montrer que, dans ces conditions, il n'y a aucune formation d'artefact de nitrosamines, même en présence de nitrites. La méthode décrite convient particulièrement bien au dosage simultané des nitrates, nitrites et TSNA contenus dans les feuilles de tabac.

\section{INTRODUCTION}

The tobacco-specific nitrosamines [TSNA] ${ }^{*}$ are by far the most abundant carcinogens found in cigarettes and other consumer tobacco products. Their concentrations often exceed the concentrations of $N$-nitrosamines in other consumer goods by hundredfold and more (1).
Two of the known TSNA, namely $N$ 'nitrosonornicotine [NNN] and 4-(methylnitrosamino)-1-(3-pyridyl)1-butanone [NNK], are powerful carcinogens which induce cancer in the nasal cavity, lung, oesophagus and liver of laboratory animals (2).

TSNA are formed during the curing and fermentation of the tobacco whereas green tobacco leaf does not contain TSNA (3). BRUNNEMaNn et al. found a correlation between the nitrate content of the tobacco and the TSNA yield (4). It is believed that nitrite which can be formed by microbial reduction of nitrate during tobacco curing and fermentation reacts with the tobacco alkaloids to form the TSNA (5).

Other authors have already reported on TSNA determinations in tobacco leaves and tobacco products (310) but they all used acidic conditions for the extraction of the TSNA and ascorbic acid to prevent artifact formation. Nitrite cannot be determined in acidic solutions because it decomposes. No method has been reported which describes the determination of nitrite, nitrate and TSNA using the same sample preparation. Usually different extraction methods were utilized for the determination of nitrite, nitrate and TSNA $(5,11)$ In tobacco products and especially in tobacco leaves wide variations in the concentrations of TSNA, nitrate and nitrite, respectively, can be observed. To investigate possible correlations between these constituents it was therefore necessary to develop a method which allows the simultaneous determination of TSNA, nitrite and nitrate using the same sample preparation.

In methods described in the literature for TSNA analysis either ${ }^{14} \mathrm{C}-\mathrm{NNN}(4,6-9)$ or nitrogen-containing compounds other than nitrosamines (5) are used as internal standards. Some authors do not use any internal standard $(3,10)$ at all. Another aim of our investigation was to find an internal standard which can be detected by the same analytical method, i.e. TEA detection, and which should have a similar recovery and similar gas chromatographic properties as the TSNA.

\section{MATERIALS AND METHODS}

\section{Reagents}

NNK was a generous gift from Dr. D. Hoffmann, Naylor Dana Institute for Disease Prevention, American Health Foundation, U.S.A., and was also obtained from Chemsyn Science Laboratories, Lenexa, Kansas, U.S.A. NDBenzA, NNN and NAB were synthesized using methods reported in the literature (12-14). The purity was $>99 \%$. Synthesis of NPePicA: 3-picolylamine

\footnotetext{
* The abbreviations used and the chemical substance prime names according to ChEMdCN ABstracts in square brackets are: TSNA for tobacoo-specific nitrosamines, NNN for $N^{2}$-nitrosonornicotine [3-(1-nitroso-2-pyrrolidiny])pyridine], NNK for 4-(methylnitrosamino)-1-(3-pyridyl)-1-buranone, NAB for $N^{*}$-nitrosoanabasine [3-(1-nitroso-2-piperidinyl)-pyridine], NAT for $N^{*}$ nitrosoanatabine [1,2,3,6-tetrahydro-1-nitroso-2, $3^{3}$-bipyridine], NDBenzA for $N$-nitrosodibenzylamine, NPePicA for $N^{\prime}$-nitrosopentylpicolylamine, TEA for thermal energy analyzer, GC for gas chromatography.
} 
$(0.2 \mathrm{M})$ in methanol and 1-bromopentane $(0.1 \mathrm{M})$ were refluxed for 3 hours. After addition of $0.2 \mathrm{M} \mathrm{KOH}$ the solution was filtrated and the solvent removed. Sodium nitrite $(10 \mathrm{~g})$ was added to the residue which was acidified with $\mathrm{HCl}(\mathrm{pH} 1)$. The nitrosamine floating on top was extracted with ether. The solvent was dried $\left(\mathrm{Na}_{2} \mathrm{SO}_{4}\right)$ and removed, and NPePicA was separated by distillation $\left(\mathrm{bP}_{(0.2 \mathrm{~mm})}: 120-124^{\circ} \mathrm{C}\right)$. Purity was $98 \%$. The spectral properties were as follows: ${ }^{1} \mathrm{H}-\mathrm{NMR}$ ( $60 \mathrm{MHz}$, in $\left[\mathrm{D}_{6}\right]$-acetone): $\delta=8.8$ to $8.4 / 7.9$ to 7.1 $\left(2 \mathrm{~m}, 4 \mathrm{H}\right.$, pyridyl-H) $5.4 / 4.9\left(2 \mathrm{~s}, 2 \mathrm{H}, \mathrm{ONN}^{-} \mathrm{CH}_{2}-\right.$ pyridyl), $4.2 / 3.5$ ( $2 \mathrm{t}, 2 \mathrm{H}, \mathrm{ONN}-\mathrm{CH}_{2}$-alkyl), 1.9 to $0.6\left(\mathrm{~m}, 9 \mathrm{H}, \mathrm{CH}_{2}-\mathrm{CH}_{2}-\mathrm{CH}_{2}-\mathrm{CH}_{3}\right)$. MS m/e: $207(\mathrm{M})$, $177(\mathrm{M}-30)$. Nicotine and nornicotine were purchased from Roth, Karlsruhe, Federal Republic of Germany. The sodium salt of ethylmercurythiosalicylic acid from Janssen Chimica, Belgium, was used as an antibacterial agent. Kieselguhr (Extrelut) was obtained from Merck, Darmstadt, Federal Republic of Germany.

All reagents used were of analytical grade.

\section{Apparatus}

GC analyses were performed with a Hewlett-Packard $5880 \mathrm{~A}$ series gas chromatograph equipped with an autoinjector and directly connected to a thermal energy analyzer (model 502 TEA, Thermo Electron Inc., Waltham, Mass., U.S.A.) as a detector with a modified furnace. Nitrite and nitrate determinations were made using a dual-channel continuous-flow analyzer (Skalar Analytical Instruments, Breda, the Netherlands) equipped with an automatic sampler, a multichannel peristaltic pump for reagents and sample delivery, and a cadmium-reducing column for nitrate-to-nitrite conversion.

\section{Tobacco Samples}

Tobacco leaves (Burley) at different stages of curing and fermentation were received from Landesanstalt für Pflanzenbau Forchheim in Rheinstetten and were stored in a freezer $\left(-70^{\circ} \mathrm{C}\right)$ until the time of analysis. The cut tobacco (Burley) was generously provided by B-A $\cdot \mathrm{T}$ Cigarettenfabriken GmbH, Hamburg, Federal Republic of Germany. The standard cigarettes (C20) were generously donated by Reemtsma Cigarettenfabriken GmbH, Hamburg, Federal Republic of Germany.

\section{Sample Preparation}

Tobacco leaves were either cut into small pieces with scissors or minced. Cigarette tobacco was directly analyzed without additional cutting.

Tobacco leaves from various stages of curing and fermentation $(5 \mathrm{~g})$ or cigarette tobacco $(4 \mathrm{~g})$, respectively, were made up to $100 \mathrm{ml}$ with $0.01 \mathrm{M} \mathrm{NaOH}$ containing $100 \mathrm{ppm}$ sodium ethylmercurythiosalicylate and al-
Figure 1.

Design of Extrelut column ( $260 \mathrm{~mm} \times 18 \mathrm{~mm}$ inside diameter) with ascorbic acid layer for alkaline extraction procedure.

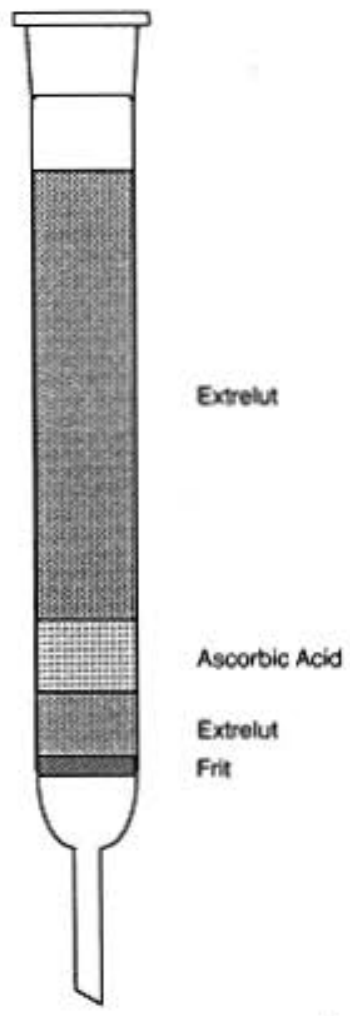

lowed to stand at room temperature for 24 hours. The amount of green leaves was adjusted so that this preparation contained approximately $4 \mathrm{~g}$ dry tobacco. Aliquots of the supernatant were used for further analysis.

\section{TSNA Extraction}

To extract TSNA from the aqueous solution two different extraction procedures were used based on a method described previously (15).

2. Alkaline Extraction Procedwre: A $10 \mathrm{ml}$ aqueous aliquot of the supernatant was diluted with water to $20 \mathrm{ml}$. NPePicA ( $1 \mu \mathrm{g}$ in $1 \mathrm{ml}$ ethanol) and/or NDBenzA ( $1 \mu \mathrm{g}$ in $1 \mathrm{ml}$ ethanol) were added as internal standards. This sample was extracted using a kieselguhr (Extrelut) extraction column (glass column: $260 \mathrm{~mm} \times 18 \mathrm{~mm}$ inside diameter, D3 grit (Figure 1)). The column was filled with Extrelut and ascorbic acid in a multilayer technique. A bottom layer (approximately $2 \mathrm{~g}$ ) of Extrelut was followed by a $5 \mathrm{~g}$ layer of ascorbic acid. The rest of the column was filled with $14 \mathrm{~g}$ Extrelut. The density of column packing was increased by vibration.

For the extraction, the aqueous sample was poured on top of the column and allowed to equilibrate for $15 \mathrm{~min}$ utes. TSNA were eluted with $35 \mathrm{ml}$ dichloromethane which was collected directly in a modified Kuderna- 
Danish concentrator consisting of a $10 \mathrm{ml}$ receiving tube with $1 \mathrm{ml}$ and $5 \mathrm{ml}$ graduation and an air-cooler with an expansion bulb.

b. Acidic Extraction Procedure: To a $10 \mathrm{ml}$ aliquot of the supernatant $1 \mu \mathrm{g} \mathrm{NPePicA}$ in $1 \mathrm{ml}$ ethanol and/or $1 \mathrm{\mu g}$ NDBenzA in $1 \mathrm{ml}$ ethanol were added as internal standards. Sodium azide $(1 \mathrm{~g})$ was added to this solution and, under continuous stirring, the solution was acidified with $3 \mathrm{ml}$ of a saturated citric acid solution $(\mathrm{pH}<4.5)$. After the addition of $7 \mathrm{ml}$ water, the sample was extracted in a similar way to the above. The glass column was prepared with $16 \mathrm{~g}$ Extrelut. After equilibration the TSNA were eluted with $35 \mathrm{ml} \mathrm{di-}$ chloromethane which was collected directly in a modified Kuderna-Danish concentrator.

Both dichloromethane extracts were treated in the same way. After addition of $1.5 \mathrm{ml} n$-hexane and 4 antibumping granules, the concentrator was placed in a heating block $\left(75-80^{\circ} \mathrm{C}\right)$ and the extracts evaporated to about $5 \mathrm{ml}$. The concentrator was allowed to cool, was rinsed with $1.5 \mathrm{ml}$ dichloromethane and the aircooler was removed. The solvent was further concentrated to $1 \mathrm{ml}$ under a gentle stream of nitrogen. The concentrate was analyzed by GC/TEA.

\section{GC Determination of TSNA}

The GC/TEA determination was performed as described by Fischer and SPIEgelhaider (16) under the following conditions: The injection-port temperature was $260^{\circ} \mathrm{C}$ and the helium carrier gas flow was $30 \mathrm{ml} /$ min. GC analyses were performed on a glass column ( $2.4 \mathrm{~m} \times 2 \mathrm{~mm}$ inside diameter) packed with $10 \%$ OV 17 on Chromosorb WHP (80/100 mesh). The GC oven temperature was programmed using a profile starting at $180^{\circ} \mathrm{C}$ with $3 \%$ min to $230^{\circ} \mathrm{C}$, held at $230^{\circ} \mathrm{C}$ for 5 minutes. The GC column was directly connected to the heated interface $\left(300^{\circ} \mathrm{C}\right)$ of the TEA detector's modified furnace $\left(500^{\circ} \mathrm{C}\right)$. With the exception of NAB and NAT all nitrosamines were baseline separated. Results were calculated by peak area comparison with the aid of an electronic integration system (Trilab 2000, SES, Nieder-Olm, Federal Republic of Germany) using an internal standard method. NPePicA and/or NDBenzA were used as internal standards. NAB and NAT were calculated as a group.

\section{Determination of Nitrite and Nitrate}

The analytical procedure is an adaptation of standard nitrite/nitrate determination (17) to a continuous flow analyzer. An aqueous aliquot (see sample preparation) was used for the determination of nitrate and nitrite using a dual-channel continuous-flow nitrite/nitrate analyzer. Nitrite was determined by diazotation of sulfanilamide and coupling with $N$-(1-naphthyl)ethylenedi- amine to form a coloured azo dye which was measured at $540 \mathrm{~nm}$ in $210 \mathrm{~mm}$ flow cell. The sensitivity range in the aqueous solution was $1 \mathrm{ppm}-50 \mathrm{ppm} \mathrm{NO}_{2}-$. Nitrate was determined as nitrite after reduction in an on-line column containing copper-cadmium together with the originally present nitrite. The nitrate concentration was calculated by subtraction. The sensitivity range was $5 \mathrm{ppm}-250 \mathrm{ppm} \mathrm{NO}_{3}-$ in the aqueous solution. Higher concentrations were reanalyzed after dilution.

\section{RESULTS AND DISCUSSION}

\section{Aqueous Extraction}

The specific difficulty of our aim to determine nitrite, nitrate and TSNA was the fact that the same sample preparation was to be used for all determinations. As nitrite decomposes in acidic solutions, an acidic extraction procedure cannot be used; either neutral or alkaline conditions are required. The suitability of different $\mathrm{NaOH}$ solutions for aqueous TSNA extraction was investigated. NNN values did not show significant differences between the different $\mathrm{NaOH}$ concentrations (Table 1). The recovery of NNK decreased considerably with increasing $\mathrm{pH}$. Losses of $\mathrm{NNK}$ at higher $\mathrm{pH}$ were mainly due to incomplete extraction. The phenomenon was not further investigated and there is no explanation for this behaviour. Stability experiments with spiked samples in $0.1 \mathrm{M} \mathrm{NaOH}$ showed that NNK and the other nitrosamines did not decompose. However, a remarkable decomposition of NNK was observed in $1 \mathrm{M} \mathrm{N2OH}$ within a period of 24 hours (about $60 \%$ ). The recovery of NAB/NAT showed a slight increase at the higher $\mathrm{NaOH}$ concentrations.

Optimum alkaline extraction conditions were achieved with $0.01 \mathrm{~m} \mathrm{NaOH}$. Under these conditions NNK was extracted with the highest efficiency. In some cases, however, a reduction in $\mathrm{NO}_{3}^{-}$concentration and formation of $\mathrm{NO}_{2}-$ were observed under these conditions; this was prevented by adding an antibacterial agent (sodium ethylmercurythiosalicylate). The decomposition of nitrate was obviously due to bacterial activity.

Table 1.

Dependence of sodlum hydroxide concentration on TSNA extraction from clgaretto tobacco (C20).

\begin{tabular}{c|c|c|c}
\hline $\begin{array}{c}\text { NaOH concentration } \\
(\mathrm{M})\end{array}$ & $\begin{array}{c}\text { NNN } \\
(\mu \mathrm{g} / \mathrm{g})\end{array}$ & $\begin{array}{c}\text { NNK } \\
(\mu \mathrm{g} / \mathrm{g})\end{array}$ & $\begin{array}{c}\text { NAB/NAT } \\
(\mu \mathrm{g} / \mathrm{g})\end{array}$ \\
\hline 0.00 & 0.90 & 0.50 & 0.65 \\
0.01 & 0.93 & 0.46 & 0.62 \\
0.02 & 1.07 & 0.44 & 0.65 \\
0.03 & 0.96 & 0.40 & 0.69 \\
0.04 & 0.97 & 0.34 & 0.70 \\
0.05 & 1.07 & 0.28 & 0.81 \\
0.10 & 1.06 & 0.28 & 0.81 \\
\hline
\end{tabular}


Table 2.

Dependence of extraction time on TSNA and nitrate extraction from elgarette tobacco (C20) uaing $0.01 \mathrm{~m} \mathrm{NaOH}$.

\begin{tabular}{c|c|c|c|c}
\hline $\begin{array}{c}\text { Time interval } \\
(\mathrm{h})\end{array}$ & $\begin{array}{c}\text { NNN } \\
(\mu / \mathrm{g})\end{array}$ & $\begin{array}{c}\mathrm{NNK} \\
(\mu \mathrm{g} / \mathrm{g})\end{array}$ & $\begin{array}{c}\mathrm{NAB} / \mathrm{NAT} \\
(\mu \mathrm{g} / \mathrm{g})\end{array}$ & $\begin{array}{c}\mathrm{NO}_{3}^{-} \\
(\mathrm{mg} / \mathrm{g})\end{array}$ \\
\hline 1 & 0.86 & 0.38 & 0.70 & 4.6 \\
2 & 0.84 & 0.38 & 0.69 & 5.1 \\
3 & 0.85 & 0.41 & 0.71 & 5.2 \\
24 & 0.96 & 0.43 & 0.74 & 6.5 \\
\hline
\end{tabular}

The extraction time influenced the amount of TSNA and nitrate extracted from the tobacco. Results from extraction experiments using different time periods are presented in Table 2. The highest extraction efficiency was achieved after 24 hours.

The aqueous extraction of TSNA, nitrate and nitrite from tobacco leaves and processed tobacco over a period of 24 hours with $20.01 \mathrm{M} \mathrm{NaOH}$ solution and the addition of an antibacterial agent gave reliable and reproducible results.

\section{Artifact Formation of TSNA}

Tobacco and tobacco products contain considerable amounts of precursor amines. The nitrosating agent, nitrite, can either be formed in tobacco leaves during curing (5) or by bacterial activity in aqueous solutions. Therefore it was necessary to investigate the efficiency of various nitrosation-preventive measures. For this purpose an aqueous alkaline extract of minced fresh

Table 3.

Effect of varlous nitrosation-preventive measures on the artifact formatton of TSNA in the course of analyals $(10 \mathrm{ml}$ allquots of tobacco leaf extracts $(4 \mathrm{~g}$ tobacco $/ 100 \mathrm{ml}$ ) containing neither TSNA nor $\mathrm{NO}_{2}^{-}$were spiked with $10 \mathrm{mg} \mathrm{NO}_{2}^{-}$and $1 \mu \mathrm{g}$ NDBenzA in $1 \mathrm{ml}$ ethanol as internal standard).

\begin{tabular}{l|c|c|c}
\hline Artifact inhibitor & $\begin{array}{c}\text { NNN } \\
(\mu g / g)\end{array}$ & $\begin{array}{c}\text { NNK } \\
(\mu g / g)\end{array}$ & $\begin{array}{c}\text { NAB/NAT } \\
(\mu g / g)\end{array}$ \\
\hline
\end{tabular}

\section{Alkallne extraction}

on Extrelut/ascorbic acid columns

n.d. n.d. n.d.

Acidic extraction on Extrelut

\begin{tabular}{|c|c|c|}
\hline $\begin{array}{l}\text { Sodium azide }(1 \mathrm{~g}) / \\
\text { citric acid }{ }^{*}(3 \mathrm{ml})\end{array}$ & n.d. & n.d. \\
\hline $\begin{array}{l}\text { Ascorbic acid }(8 \mathrm{ml}) / \\
\text { citric acid* }(1 \mathrm{ml})\end{array}$ & 0.44 & n.d. \\
\hline $\begin{array}{l}\text { Ammonlum sulphamate }(1 \mathrm{~g}) / \\
\text { citric acid }(2 \mathrm{ml})\end{array}$ & 4.63 & n.d. \\
\hline
\end{tabular}

- Saturated solution.

n.d. = not detected (NNN, NAB/NAT: $<0.02 \mu \mathrm{g} / \mathrm{g}$ tobacco NNK: $<0.03 \mu g / g$ tobacco). green tobacco leaves $(4 \mathrm{~g}$ tobacco $/ 100 \mathrm{ml}$ ) was prepared. Aliquots $(10 \mathrm{ml})$ of this test extract containing neither TSNA nor nitrite, were spiked with $10 \mathrm{mg}$ $\mathrm{NO}_{2}^{-}$and $1 \mu \mathrm{g} \mathrm{NDBenzA}$ as internal standard. The following nitrosation-inhibiting procedures were tested: alkaline extraction procedure on Extrelut/ascorbic acid columns, and an acidic extraction procedure with three different nitrosation inhibitors (sodium azide, ascorbic acid and ammonium sulphamate respectively in the presence of citric acid).

No artifact formation was observed using the alkaline extraction method or the acidic extraction method in combination with sodium azide as a nitrosation inhibitor (Table 3). Ascorbic acid and especially ammonium sulphamate were shown not to inhibit the formation of NNN and NAB/NAT effectively, whereas under the same conditions formation of NNK was not observed. The alkaline extraction procedure and the acidic extraction procedure with sodium azide can be used just as successfully for TSNA analysis.

\section{Column Extraction of TSNA}

In nitrosamine analysis columns filled with granular support material were used successfully for the extraction of aqueous samples (16). The efficiency and practicability of this method seem to be superior to liquidliquid partition extraction. TSNA were extracted using kieselguhr (Extrelut) with high recovery rates.

Nicotine interferes with the GC/TEA determination of TSNA (16). Owing to alkaline extraction, nicotine is present in the aqueous extracts and therefore has to be removed. This was achieved by two different extraction methods.

1. Alkaline Extraction Method: The alkaline extracts were poured directly onto the extraction column and nicotine was removed completely by a $5 \mathrm{~g}$ layer of ascorbic acid at the lower part of the extraction column (Figure 1).

2. Acidic Extraction Method: As acidic extraction is performed at a $\mathrm{pH}$ of about 4.5 , nicotine is not eluted with dichloromethane from the extraction column.

Both methods were compared in a set of different tobacco leaf samples. The results, presented in Table 4, show good agreement between the two procedures employed in the methodology. The alkaline and the acidic extraction method were utilized with high accuracy for TSNA analysis without artifact formation. The acidic extraction method is recommended in cases where nitrite is present in the tobacco sample. In all other cases the alkaline extraction method is preferred due to its better practicability.

\section{Recovery Studies for TSNA Determination}

A basic demand of analytical procedures is that the recovery can be estimated by using an internal standard 
Table 4.

Comparison of results of TSNA In different tobacco leaves and cigarette tobacco using the alkaline and the acidic extraction mothode (samples A, B, C, D, E, F: Burley tobacco leaves from various stalk positions at different stages of drying; sample G: cigarette tobacco).

\begin{tabular}{|c|c|c|c|c|}
\hline Sample & $\begin{array}{l}\text { Extraction } \\
\text { method }\end{array}$ & $\begin{array}{c}\text { NNN } \\
(\mu g / \\
g \text { tobacco) }\end{array}$ & $\begin{array}{c}\text { NNK } \\
(\mu g / \\
g \text { tobacco) }\end{array}$ & $\begin{array}{c}\text { NAB/NAT } \\
(\mu \mathrm{g} / \\
\mathrm{g} \text { tobacco) }\end{array}$ \\
\hline \multirow[t]{2}{*}{$A$} & alkaline & 0.16 & 0.23 & 0.16 \\
\hline & acidic & 0.16 & 0.25 & 0.19 \\
\hline B & alkaline & 0.51 & 0.33 & 0.73 \\
\hline " & acidic & 0.57 & 0.42 & 0.77 \\
\hline \multirow[t]{2}{*}{ C } & alkaline & 0.20 & n.d. & n.d. \\
\hline & acidic & 0.38 & n.d. & n.d. \\
\hline \multirow[t]{2}{*}{ D } & alkaline & 0.63 & n.d. & n.d. \\
\hline & acidic & 0.57 & n.d. & n.d. \\
\hline \multirow[t]{2}{*}{$E$} & alkaline & 0.03 & n.d. & n.d. \\
\hline & acidic & 0.05 & n.d. & n.d. \\
\hline \multirow[t]{2}{*}{$F$} & alcaline & 60.00 & n.d. & n.d. \\
\hline & acidic & 67.00 & n.d. & n.d. \\
\hline \multirow[t]{2}{*}{$\mathbf{G}$} & alcaline & 2.96 & 0.85 & 2.04 \\
\hline & acidic & 3.08 & 0.98 & 2.12 \\
\hline
\end{tabular}

n. d. - not detected (NNN, NAB/NAT: $<0.02 \mu \mathrm{g} / \mathrm{g}$ tobacco, NNK: $<0.03 \mu \mathrm{g} / \mathrm{g}$ tobacco).

whose recovery should preferably be determined by the same detection method. So far, no reported method describes the use of a non-labelled nitrosamine as an internal standard for the analysis of TSNA in tobacco leaves and processed tobacco. NDBenzA and NPePicA were shown to be suitable internal standards for the analysis of TSNA in tobacco smoke (16). Accordingly, their possible use for analyzing TSNA in tobacco leaves and processed tobacco was investigated. The recoveries of both internal standards were determined in compar- ison to the recovery of each TSNA. Minced fresh green tobacco leaves $(3 \mathrm{~g})$ containing no TSNA were spiked in a $3 \mu \mathrm{g} / \mathrm{g}$ tobacco level of each TSNA prior to aqueous extraction (exact amounts are given in Table 5). Both internal standards were added to the aliquots of the aqueous extracts. In Table 5 the recovery rates of the internal standards for both extraction procedures are presented. In both cases the recovery rate of NPePicA was significantly higher than that of NDBenzA. The recoveries of the added TSNA were calculated using the amounts determined by internal standardization method for both internal standards in relation to the added TSNA amount. A relative recovery of $100 \%$ represents a correct internal standardization. In comparison the results calculated on NPePicA were closer to $100 \%(2 \%-5 \%$ deviation) than the results calculated on NDBenzA ( $6 \%-17 \%$ deviation). Consequently, NPePicA is more suitable than NDBenzA for internal standardization in TSNA analysis of tobacco leaves.

In another experiment, both internal standards were added before aqueous extraction. The recovery for $\mathrm{NPePicA}$ was only $85 \%$ which resulted in an overestimation of $8 \%$ to $12 \%$ in the TSNA. The recovery of NDBenzA, when added before aqueous extraction, was only $20 \%$ to $23 \%$. The low recovery observed may have been caused by non-specific interaction of NDBenzA with tobacco constituents and, therefore, NDBenzA does not reflect the efficiency of the aqueous extraction procedure. The best results were obtained using NPePicA as internal standard after aqueous extraction.

A similar recovery study was performed with cut tobacco. In this case, the preformed TSNA in tobacco were first determined and calculated using both internal standards. The tobacco was spiked with TSNA in a $2.5 \mu \mathrm{g} / \mathrm{g}$ tobacco level and the resulting TSNA concentrations were determined using both internal standards (exact amounts are given in Table 6). The recoveries of the added nitrosamines were individually determined for both internal standards and are pre-

Table 5

Percentage recovery of the internal standards NPePICA and NDBenzA and standardized recovery rates of TSNA relative to NPePicA and NDBenzA, respectlvely, determined in fresh tobacco leaves. Before aqueous extraction the following amounts were added: $3010 \mathrm{ng} / \mathrm{g}$ tobacco NNN, $3200 \mathrm{ng} / \mathrm{g}$ tobacco NNK and $2840 \mathrm{ng} / \mathrm{g}$ tobacco NAB/NAT.

Addition of internal standerds after aqueous extraction: $3200 \mathrm{ng} / \mathrm{g}$ tobacco NPePicA and $3330 \mathrm{ng} / \mathrm{g}$ tobacco NDBenzA.

\begin{tabular}{lc|c|c|c|c|c|c|c} 
& \multicolumn{2}{c|}{$\begin{array}{c}\text { Recovery (\%) of } \\
\text { internal standards }\end{array}$} & \multicolumn{2}{c|}{$\begin{array}{c}\text { Corrected recovery (\%) } \\
\text { calculated relative to NPePicA* }\end{array}$} & \multicolumn{3}{c}{$\begin{array}{c}\text { Corrected recovery (\%) } \\
\text { calculated relative to NDBenzA* }\end{array}$} \\
\cline { 2 - 9 } & NPePicA & NDBenzA & NNN & NNK & NAB/NAT & NNN & NNK & NAB/NAT \\
\hline Alkaline & 92 & 85 & 96 & 97 & 96 & 106 & 107 & 105 \\
column extraction & \pm 2.5 & \pm 2.5 & \pm 2.4 & \pm 1.9 & \pm 3.3 & \pm 1.8 & \pm 2.2 & \pm 2.7 \\
Acidic & 96 & 83 & 98 & 96 & 95 & 117 & 115 & 114 \\
column extraction & \pm 4.5 & \pm 1.9 & \pm 6.2 & \pm 4.9 & \pm 6.2 & \pm 7.6 & \pm 5.9 & \pm 8.0 \\
\hline
\end{tabular}

\footnotetext{
* A corrected recovery of $100 \%$ means same recovery as internal standard.
} 
Table 6.

Recovery rates of TSNA, NPePIcA and NDBenzA for the analysis of cut tobacco

(the tobacco was the same as used for the repeatability experiment, for original TSNA content

refer to Table 7A; spiking level: $2400 \mathrm{ng} / \mathrm{g}$ tobacco NPePicA, $2500 \mathrm{ng} / \mathrm{g}$ tobacco NDBenzA,

$2260 \mathrm{ng} / \mathrm{g}$ tobacco NNN, $2400 \mathrm{ng} / \mathrm{g}$ tobacco NNK and $2130 \mathrm{ng} / \mathrm{g}$ tobacco NAB/NAT were added).

\begin{tabular}{|c|c|c|c|c|c|c|c|c|}
\hline & \multicolumn{2}{|c|}{$\begin{array}{l}\text { Recovery }(\%) \text { of } \\
\text { internal standards }\end{array}$} & \multicolumn{3}{|c|}{$\begin{array}{l}\text { Corrected recovery (\%) } \\
\text { calculated relative to NPePicA* }\end{array}$} & \multicolumn{3}{|c|}{$\begin{array}{c}\text { Corrected recovery (\%) } \\
\text { calculated relative to NDBenzA* }\end{array}$} \\
\hline & NPePicA & NDBenzA & NNN & NNK & NAB/NAT & NNN & NNK & NAB/NAT \\
\hline $\begin{array}{l}\text { Alkaline } \\
\text { column extraction }\end{array}$ & $\begin{array}{r}93 \\
\pm 3.5\end{array}$ & $\begin{array}{r}84 \\
\pm 4.0\end{array}$ & $\begin{array}{r}93 \\
\pm 4.8\end{array}$ & $\begin{array}{r}95 \\
\pm 1.0\end{array}$ & $\begin{array}{r}89 \\
\pm 4.7\end{array}$ & $\begin{array}{l}106 \\
\pm 18\end{array}$ & $\begin{array}{r}98 \\
\pm 8.0\end{array}$ & $\begin{array}{r}99 \\
\pm 9.0\end{array}$ \\
\hline $\begin{array}{l}\text { Acidic } \\
\text { column extraction }\end{array}$ & $\begin{array}{r}90 \\
\pm 2.8\end{array}$ & $\begin{array}{r}73 \\
+2.4\end{array}$ & $\begin{array}{r}81 \\
+5.6\end{array}$ & $\begin{array}{r}90 \\
\pm 3.8\end{array}$ & $\begin{array}{r}81 \\
\pm 4.7\end{array}$ & $\begin{array}{r}114 \\
\pm 11\end{array}$ & $\begin{array}{r}118 \\
\pm 5.7\end{array}$ & $\begin{array}{r}108 \\
\pm 7.0\end{array}$ \\
\hline
\end{tabular}

* A corrected recovery of $100 \%$ means same recovery as internal standard.

sented in Table 6. The recovery for alkaline column extraction was higher for both internal standards (NPePicA 93\%, NDBenzA 84\%) as compared to acidic column extraction (NPePicA 90\%, NDBenzA 73\%). Using NPePicA for calculation, the TSNA concentrations were underestimated in both extraction methods whereas using NDBenzA for calculation resulted in an overestimation, except for NNK and NAB/NAT, in alkaline column extraction. The recovery rates of the TSNA for both extraction methods were in a similar range for both internal standards. Using NPePicA as the internal standard, the standard deviation.was much lower than that obtained with NDBenzA.

With the above-mentioned limitations both NPePicA and NDBenzA are suitable compounds for internal standardization in the TSNA analysis of tobacco leaves and processed tobacco.

\section{Criteria for Reliability of TSNA Analysis}

Chemiluminescence detection in combination with gas chromatography is highly specific for compounds generating NO upon pyrolysis. In all analyses only peaks associated with nitrosamines were detected.

Nicotine interferes with the GC/TEA determination of TSNA (16) and had therefore to be removed to achieve reliable results. For the alkaline column extraction this was achieved with the aid of an ascorbic acid layer in the extraction column. The acidic extraction method required no further removal of nicotine because it does not elute with dichloromethane from the Extrelut column.

The minimum detection limit was $15 \mathrm{ng}-25 \mathrm{ng} / \mathrm{g}$ dry mass for NNN and NAB/NAT and $25 \mathrm{ng}-50 \mathrm{ng} / \mathrm{g}$ dry mass for NNK with a GC/TEA detection limit of $0.15 \mathrm{ng}-0.25 \mathrm{ng} /$ injection.

The repeatability of TSNA analysis was determined for cut tobacco and tobacco leaves using both extraction procedures. The TSNA content of tobacco leaves is not evenly distributed. It is therefore very difficult to prepare homogeneous samples for a repeatability study. To exclude this influencing factor aliquots of pooled aqueous extracts were also analyzed. Results were calculated using NPePicA and NDBenzA as internal standards and are presented in Table 7. Cut tobacco was analyzed with very good repeatability. Using NPePicA as an internal standard resulted in better repeatability (coeff. of var. $2 \%-6 \%$ ) than with NDBenzA (coeff. of var. $1.4 \%-10.4 \%$ ) whereas the standard deviation for the analysis of individual tobacco leaf samples was generally higher for both internal standard methods. This was obviously due to uneven nitrosamine distribution in the tobacco leaf samples. This conclusion is supported by the low standard deviation obtained from pooled aqueous extracts (see Table 7 (B2)). The concentration of NNK in the tobacco leaf samples was near the lower limit of determination. Therefore the relatively high standard deviation for NNK was not surprising.

The good reproducibility of the method in combination with high recovery rates for both internal standards and for TSNA, and the effective inhibition of artifact formation accounts for good reliability and high accuracy in the TSNA analysis of tobacco leaves and processed tobacco.

\section{Criteria for Reliability of Nitrate/Nitrite Analysis}

The nitrate and nitrite analysis was performed according to standard analytical procedures. Several parameters influencing the nitrate/nitrite estimation were investigated.

1. Necessity for an Antibacterial Agent: As described, the sodium hydroxide concentration has to be relatively low for the extraction of TSNA from tobacco leaves and processed tobacco in order to ensure complete extraction of NNK. Under these conditions, however, a microbial reduction of nitrate to nitrite was observed in some cases; this was successfully inhibited by using sodium ethylmercurythiosalicylate as an antibacterial agent. 
Table 7.

Comparison of the repeatablity of TSNA analysis in cut tobacco and tobacco leaves using NPePicA and NDBenzA as internal standards (alkaline versus acidic column extraction; $n=4$ ).

\begin{tabular}{c|c|c|c|c|c}
\hline \multicolumn{2}{c|}{$\begin{array}{c}\text { Results calculated using } \\
\text { NPePicA as internal standard }\end{array}$} & \multicolumn{3}{c}{$\begin{array}{c}\text { Results calculated using } \\
\text { NDBenzA as internal standard }\end{array}$} \\
\hline NNN & NNK & NAB/NAT & NNN & NNK & NAB/NAT \\
$(\mathrm{ng} / \mathrm{g})$ & $(\mathrm{ng} / \mathrm{g})$ & $(\mathrm{ng} / \mathrm{g})$ & $(\mathrm{ng} / \mathrm{g})$ & $(\mathrm{ng} / \mathrm{g})$ & $(\mathrm{ng} / \mathrm{g})$ \\
\hline
\end{tabular}

\begin{tabular}{|c|c|c|c|c|c|c|}
\hline \multicolumn{7}{|l|}{ A. Cut tobacco } \\
\hline alkaline column extraction & $\begin{array}{l}5990 \\
\pm 122\end{array}$ & $\begin{array}{l}1560 \\
\pm 40\end{array}$ & $\begin{array}{l}3230 \\
\pm 112\end{array}$ & $\begin{array}{l}6730 \\
\pm 94\end{array}$ & $\begin{array}{l}1720 \\
\pm 31\end{array}$ & $\begin{array}{l}3630 \\
\pm 109\end{array}$ \\
\hline acidic column extraction & $\begin{array}{l}6060 \\
\pm 157\end{array}$ & $\begin{array}{l}1700 \\
\pm 103\end{array}$ & $\begin{array}{r}3290 \\
\pm 85\end{array}$ & $\begin{array}{l}7310 \\
\pm 410\end{array}$ & $\begin{array}{l}2030 \\
\pm 212\end{array}$ & $\begin{array}{l}3960 \\
\pm 182\end{array}$ \\
\hline \multicolumn{7}{|l|}{ B. Tobacco leaves } \\
\hline \multicolumn{7}{|l|}{ 1. Individual samples": } \\
\hline $\begin{array}{l}\text { alkaline } \\
\text { column extraction }\end{array}$ & $\begin{array}{l}1780 \\
\pm 107\end{array}$ & $\begin{array}{l}38 \\
\pm 7\end{array}$ & $\begin{array}{l}290 \\
\pm 22\end{array}$ & $\begin{array}{l}2030 \\
\pm 124\end{array}$ & $\begin{array}{l}44 \\
\pm 9\end{array}$ & $\begin{array}{l}330 \\
\pm 23\end{array}$ \\
\hline $\begin{array}{l}\text { acidic } \\
\text { column extraction }\end{array}$ & $\begin{array}{l}1760 \\
\pm 154\end{array}$ & $\begin{array}{l}68 \\
\pm 18\end{array}$ & $\begin{array}{l}230 \\
\pm 28\end{array}$ & $\begin{array}{l}2080 \\
\pm 222\end{array}$ & $\begin{array}{l}80 \\
\pm 22\end{array}$ & $\begin{array}{l}270 \\
\pm 38\end{array}$ \\
\hline \multicolumn{7}{|l|}{ 2. Aliquots of pool sample": } \\
\hline $\begin{array}{l}\text { alkaline } \\
\text { column extraction }\end{array}$ & $\begin{array}{l}1780 \\
\pm 21\end{array}$ & $\begin{array}{c}34 \\
\pm 29\end{array}$ & $\begin{array}{l}260 \\
\pm 11\end{array}$ & $\begin{array}{c}2030 \\
\pm 48\end{array}$ & $\begin{array}{c}39 \\
\pm 33\end{array}$ & $\begin{array}{l}300 \\
\pm 14\end{array}$ \\
\hline $\begin{array}{l}\text { acidic } \\
\text { column extraction }\end{array}$ & $\begin{array}{l}1780 \\
\pm 18\end{array}$ & $\begin{array}{l}29 \\
\pm 7\end{array}$ & $\begin{array}{l}208 \\
\pm 24\end{array}$ & $\begin{array}{l}2080 \\
\pm 45\end{array}$ & $\begin{array}{l}34 \\
\pm 9\end{array}$ & $\begin{array}{l}244 \\
\pm 30\end{array}$ \\
\hline
\end{tabular}

" For experiment B1 individual samples were prepared by subdividing minced tobacco leaves; for experiment B2 aliquots of a pool sample prepared by taking equal parts of the aqueous extracts from experiment B1 were taken for analysis.

2. Concentration of $\mathrm{NaOH}$ during Aqueous Extraction: The values presented in Table 8 show that nitrate and nitrite in tobacco leaves can be determined over a wide $\mathrm{pH}$ range in the presence of an antibacterial agent.

3. Duration of Aqueous Extraction: The extraction of nitrate and nitrite from fresh tobacco leaves with $0.01 \mathrm{M}$ $\mathrm{NaOH}$ containing an antibacterial agent is not greatly influenced by time (Table 9). The extraction of nitrate from cigarette tobacco, however, showed an increase with time (Table 2).

4. Repeatability: The repeatability of the nitrate and nitrite determination was determined with both fresh tobacco leaves and cut tobacco. For tobacco the mean

Table 8.

Determination of nitrate and nitrite from fresh tobacco leaves using sodlum hydroxlde in different concentrations. With the exception of $1 \mathrm{M} \mathrm{NaOH}$ the extraction was carried out in the presence of an antibacterial agent.

\begin{tabular}{l|c|c}
\hline NaOH concentration $(\mathrm{M})$ & $\begin{array}{c}\text { Nitrate } \\
(\mathrm{mg} / \mathrm{g})\end{array}$ & $\begin{array}{c}\text { Nitrite } \\
(\mathrm{mg} / \mathrm{g})\end{array}$ \\
\hline $0.00+$ antibacterial agent & 3.3 & 0.06 \\
$0.01+$ antibacterial agent & 3.1 & 0.09 \\
$0.05+$ antibacterial agent & 3.2 & 0.09 \\
$0.10+$ antibacterial agent & 3.3 & 0.06 \\
1.00 & 3.1 & 0.08 \\
\hline
\end{tabular}

value of 8 analyses was $37.4 \pm 1.18 \mathrm{mg} / \mathrm{g}$ tobacco for nitrate. For tobacco leaves the mean value of 8 analyses was $3.3 \pm 0.15 \mathrm{mg} / \mathrm{g}$ tobacco for nitrate and $0.08 \pm$ $0.009 \mathrm{mg} / \mathrm{g}$ tobacco for nitrite. The investigation of parameters influencing the nitrate/nitrite determination showed that the addition of an antibacterial agent, the use of $0.01 \mathrm{M} \mathrm{NaOH}$, and an extraction time of $24 \mathrm{~h}$ resulted in accurate and reproducible results.

\section{CONCLUSIONS}

The method described is shown to be suitable for the determination of TSNA and of nitrate/nitrite in tobacco leaves and processed tobacco. Aqueous extrac-

Table 9.

Determination of nitrate and nitrite from fresh tobacco leaves with $0.01 \mathrm{~m} \mathrm{NaOH}$ containing an antibacterial agent, using different extraction times.

\begin{tabular}{c|c|c}
\hline $\begin{array}{c}\text { Time interval } \\
(\mathrm{h})\end{array}$ & $\begin{array}{c}\text { Nitrate } \\
(\mathrm{mg} / \mathrm{g})\end{array}$ & $\begin{array}{c}\text { Nitrite } \\
(\mathrm{mg} / \mathrm{g})\end{array}$ \\
\hline 1 & 3.2 & 0.1 \\
2 & 3.4 & 0.1 \\
3 & 3.4 & 0.1 \\
24 & 3.4 & 0.1 \\
\hline
\end{tabular}


tion under alkaline conditions in the presence of an antibacterial agent permits the simultaneous extraction of TSNA and nitrate/nitrite. Under these conditions, artifact formation can effectively be inhibited. The further clean-up procedure includes two alternative extraction procedures for TSNA: acidic column extraction, which is preferred when nitrite is present, and alkaline column extraction which is normally preferred due to its better practicability and higher accuracy. With internal standardization either by NPePicA or by NDBenzA it is possible to determine the recovery of the internal standards by the same detection method as used for the TSNA.

\section{REFERENCES}

1. Hoffmann, D., and S. S. Hecht: Nicotine-derived $\mathrm{N}$-nitrosamines and tobacco-related cancer - Current status and future directions; Cancer Res. 45 (1985) 935-944.

2. Hoffmann, D., and S. S. Hecht: Tobacco and tobacco smoke (Volatile and tobacco-specific nitrosamines - general aspects); in Environmental carcinogens - Selected methods of analysis, Vol. 6: $N$-Nitroso compounds, edited by $\mathrm{H}$. Egan, R. Preussmann, I. K. O'Neill, G. Eisenbrand, B. Spiegelhalder, H. Bartsch, International Agency for Research on Cancer, Lyon, IARC Sci. Publ. No. 45, 1983, pp. 63-67.

3. Chamberlain, W. J., J. L. Baker, O. T. Chortyk and M. G. Stephenson: Studies on the reduction of nitrosamines in tobacco; Tob. Sci. 30 (1986) 81-82.

4. Brunnemann, K. D., J. Masaryk and D. Hoffmann: Role of tobacco stems in the formation of $N$ nitrosamines in tobacco and cigarette mainstream and sidestream smoke; J. Agric. Food. Chem. 31 (1983) 1221-1224.

5. Andersen, R. A., H. R. Burton, P. D. Fleming, T. R. Hamilton-Kemp and S. L. Gay: Effects of an aircuring environment on alkaloid-derived nitrosamines in Burley tobacco; in Relevance of $\mathrm{N}$-nitroso compounds to human cancer - Exposures and mechanisms, edited by $H$. Bartsch, I. K. $O^{\prime}$ Neill and R. Schulte-Hermann, International Agency for Research on Cancer, Lyon, IARC Sci. Publ. No. 84, 1987, 451-455.

6. Adams, J. D., P. Owens-Tucciarone and D. Hoffmann: Tobacco-specific $N$-nitrosamines in dry snuff; Food Chem. Toxicol. 25 (1987) 245-246.

7. Adams, J. D., K. D. Brunnemann and D. Hoffmann: Chemical studies on tobacco smoke, LXXV. Rapid method for the analysis of tobacco-specific $\mathrm{N}$-nitrosamines by gas-liquid chromatography with a thermal energy analyser; J. Chromatogr. 256 (1983) 347-351.

8. Hoffmann, D., J. D. Adams, K. D. Brunnemann and S. S. Hecht: Assessment of tobacco-specific $N$ nitrosamines in tobacco products; Cancer Res. 39 (1979) 2505-2509.
9. Hecht, S. S., J. D. Adams and D. Hoffmann: Tobacco-specific nitrosamines in tobacco and tobacco smoke; in Environmental carcinogens Selected methods of analysis, Vol. 6: $\mathrm{N}$-Nitroso compounds, edited by $\mathrm{H}$. Egan, R. Preussmann, I. K. O'Neill, G. Eisenbrand, B. Spiegelhalder, H. Bartsch, International Agency for Research on Cancer, Lyon, IARC Sci. Publ. No. 45, 1983, 93-101.

10. Bhide, S. V., J. Nair, G. B. Maru, U. J. Nair, B. V. Kameshwar Rao, M. K. Chakraborty and K. D. Brunnemann: Tobacco-specific $N$-nitrosamines (TSNA) in green mature and processed tobacco leaves from India; Beitr. Tabakforsch. Int. 14 (1987) 29-32.

11. Andersen, R. A., and T. R. Kemp: Accumulation of 4-( $N$-methyl- $N$-nitrosamino)-1-(3-pyridyl)-1-butanone in alkaloid genotypes of Burley tobacco during postharvest processing - Comparisons with $N$ 'nitrösonornicotine and probable nitrosamine precursors; Cancer Res. 45 (1985) 5287-5293.

12. $\mathrm{Hu}, \mathrm{M}$. W., W. E. Bondinell and D. Hoffmann: Chemical studies on tobacco smoke, XXIII. Synthesis of carbon-14 labelled myosmine, nornicotine and $N^{\prime}$-nitrosonornicotine; J. Labelled Compd. 10 (1974) 79-88.

13. Hecht, S. S., R. M. Ornaf and D. Hoffmann: Chemical studies on tobacco smoke, XXXIII. $N$ '-Nitrosonornicotine in tobacco - Analysis of possible contributing factors and biological implications; J. Natl, Cancer Inst. 54 (1975) 1237-1244.

14. Druckrey, H., R. Preussmann, S. Ivankovic and D. Schmähl: Organotrope carcinogene Wirkungen bei 65 verschiedenen $\mathrm{N}$-Nitroso-Verbindungen an $\mathrm{BD}$ Ratten; Z. Krebsforsch. 69 (1967) 103-201.

15. Spiegelhalder, B., G. Eisenbrand and R. Preussmann: Volatile $N$-nitrosamines in beer and other beverages by direct extraction using a kieselguhr column; in Environmental carcinogens - Selected methods of analysis, Vol. 6: N-Nitroso compounds, edited by H. Egan, R. Preussmann, I. K. O'Neill, G. Eisenbrand, B. Spiegelhalder, H. Bartsch, International Agency for Research on Cancer, Lyon, IARC Sci. Publ. No. 45, 1983, 135-142.

16. Fischer, S., and B. Spiegelhalder: Improved method for the determination of tobacco-specific nitrosamines (TSNA) in tobacco smoke; Beitr. Tabakforsch. Int. 14 (1989) 145-153.

17. Spiegelhalder, B., G. Eisenbrand and R. Preussmann: Influence of dietary nitrate on nitrite content of human saliva - Possible relevance to in vivo formation of $\mathrm{N}$-nitroso compounds; Food Cosmet. Toxicol. 14 (1976) 545-548.

\section{Acknowledgement}

The authors are grateful to Ingeborg Hofmann, Inge Kling, Eva Schleicher and Gerd Würtele for skillful technical assistance. The authors wish to thank Otto Zelezny for the 
synthesis of $N^{\prime}$-nitrosopentylpicolylamine. One of us (S.J. $K$.) would like to thank the German Cancer Research Center, Heidelberg, Federal Republic of Germany, for financial support during bis tenure as a visiting scientist at the Institwite of Toxicology and Chemotherapy. One of us (S. F.) has been granted a doctorate fellowship of the FriedrichEbert-Stiftung wbich is gratefully acknowledged.
Authors' address:

Deutsches Krebsforschungszentrum, Institut für Toxikologie und Chemotherapie, Im Newenheimer Feld 280,

Postfach: 101949 ,

D-6900 Heidelberg 1. 